\begin{tabular}{c} 
Revista de Journal of Integrated \\
GESTÃO COSTEIRA Integrada COSTAL ZONE MANAGEMENT \\
\hline
\end{tabular}

\title{
Animal welfare concerns at a fish farming operation in southeastern Brazil
}

\author{
Diego Andre Rodrigues ; Alberto Geraldo Carleti Junior ; \\ Wagner Cezario Balista ${ }^{a}$; Rodrigo Randow de Freitas ${ }^{\circledR}$, a
}

\begin{abstract}
Concerns for the welfare of fish during the farming/production process is in its infancy when compared to other species. This is due to disputes in the interpretation of characteristics that suggest awareness in fish, a concern that is somewhat widespread among consumers and producers. Through questionnaires, this study aimed to highlight what the members of a fishermen's association (that farm Tilapia and Robalo Peva) understand about the welfare of fish, and whether it is considered during the production process. In addition, although there are still many controversies, this perception has been changing in recent years, in part due to anatomical, physiological and behavioral evidence that suggest fish are sentient (are aware of sensations, have subjective feelings). Moreover, as the consumer has become aware of the issues, concern for animal welfare has increased, leading to a need for the market to adapt to these requirements.
\end{abstract}

Key words: Fisheries, Aquaculture, Animal welfare, Fish farming, Sentient

\section{RESUMO}

Considerações quanto ao bem-estar animal em uma operação de cultivo de peixes no sudeste do Brasil

A preocupação com o bem-estar dos peixes durante os processos a produção e processamento do pescado é embrionária se comparada com outras espécies, devido à existência de controvérsias sobre a interpretação de características que sugerem a consciência deles. Assim, através de questionários, o presente estudo tem por objetivo, evidenciar o que os membros de uma associação de pescadores, que cultiva tilápias e robalos-peva, conhecem sobre o bem-estar animal, e se ele é considerado durante o processo de produção. Sendo que, embora ainda haja várias controvérsias, essa situação vem se alterando nos últimos anos, devido a evidências anatômicas, fisiológicas e comportamentais que sugerem que eles também são sencientes (tem capacidade de ter consciência de sensações, ter sentimentos subjetivos). Além disso, à medida que o consumidor tem consciência do assunto, o bem-estar animal tem se tornado uma preocupação crescente, que conduzirá a uma necessidade de adaptação do mercado quanto a essa exigência.

Palavras-chave: Pescadores, Aquicultura, Bem-estar animal, Piscicultura, Sencientes.

(a) Corresponding author to whom correspondence should be addressed.

${ }^{\text {a }}$ Universidade Federal do Espírito Santo, Centro Universitário Norte do Espírito Santo, Departamento de Engenharias e Tecnologia DETEC, Laboratório de Gestão Costeira - Aquicultura e Pesca (LGCap), Rodovia BR 101 Norte, Km. 60, Litorâneo, 29932-540, São Mateus, ES, Phone/Fax: 55 (Brazil) 27 3312-1710. e-mails: Rodrigues <diegoandrerodrigues.12@gmail.com>; Carleti Júnior <alberto_carletti@hotmail.com>; Balista,<wcezario@hotmail.com>; Freitas <digorandow@gmail.com>

* Submission: 28 AUG 2014; Peer review: 25 SEP 2014; Revised: 3 NOV 2014; Accepted: 6 NOV 2013; Available on-line: 7 NOV 2014
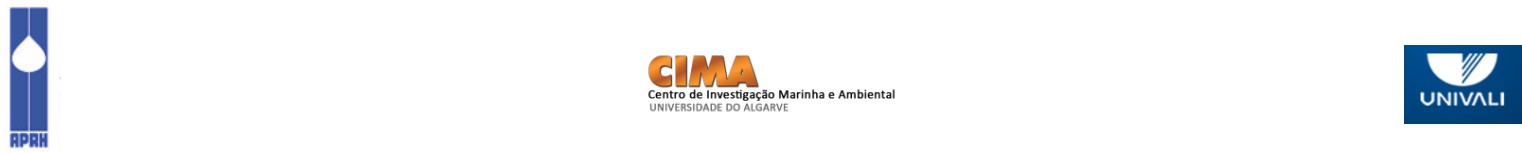


\section{Introduction}

Concern for the welfare of animals (non-human) has existed for a long time, however, throughout the years; various ideas have tarnished this concern by questioning the capability for suffering and awareness in animals (Volpato, 2007). Since Harrison (1964) published his work that looked at excessive abuses in the commercial production of animals, scientific concerns about animal welfare have increased, especially regarding mammals and birds. However, interest in this subject as it relates to welfare of fish, is relatively recent (1990s) and increased at the beginning of the $21^{\text {st }}$ century (Anonymous, 2006; Galhardo \& Oliveira, 2006; Volpato, 2007).

Studies concerning the welfare of fish began after Rose (2002) published his work on the neurobehavioral nature of fishes and the question of awareness and pain. This work led to great fanfare in scientific circles. According to the author, there are no anatomical evidence to justify the feeling of pain in fish and any future work that proposition for the existence of consciousness in fish (or other neurologically-comparable vertebrate species),, should provide a compelling empirical basis. Furthermore, also states that the perception of pain or any other physiological only have implications for the well-being of fish, if achieving elevated brain levels (Volpato, 2007).

Based on these assertions, a series of studies have attempted to demonstrate the basic neuroanatomical and physiology of pain perception in fish. The work started in the laboratory of Victoria Braithwaite (Odling-Smee \& Braithwaite, 2003; Sneddon et al., 2003; Brown \& Braithwaite, 2005) has contributed to the empirical support of sentience in fish, serving as a basis for studies by Sneddon (Sneddon, 2002, 2003a,b; Sneddon et al., 2003). From the methodological point of view, both Braithwaite and Sneddon (as well Rose) tested for empirical evidence inferring that fish are sentient beings (Volpato, 2007) using the same methodology.

Other authors (Sandoe et al., 2004; Dawkins, 2006; Duncan, 2006; Volpato et al., 2007) have shown the inability of these empirical methods to demonstrate sentience in non-human organisms, including fish (Volpato, 2007). However, Volpato et al. (2007) noted that the method is also unable to prove the absence of sentience. This lead to a the suggestion of an ethical premise in which fish may be sentient beings, and while not having to prove whether they are or not, common sense would dictate that these animals should be treated as such. Moreover, the largest body of scientific studies points indirectly to the idea that fish are sentient beings (Volpato, 2007).

Currently, the literature recognizes that in order to justify the welfare in fish, it would be necessary to show that these organisms are aware of a state of distress or discomfort. At the most rudimentary level of consciousness (the basis of concept of sentience), animals have to the capacity to perceive basic processes such as pain, heat, cold. Sentience is an attribute that animals must have in order for people to be concerned for their welfare (Volpato, 2007).

Indeed, concern for the welfare of the fish during the production process is not very common among consumers and producers as suggested by the scant literature on the subject, more specifically in the area of animal welfare (Rollin, 1995; Fraser \& Broom, 1996; Benson \& Rollin, 2004; Vaarst et al., 2004; Carneiro et al., 2007). However, this scenario is gradually changing, with increasing international publications, reports and books devoted to the welfare of fish (Erickson, 2003; Branson, 2008; Pedrazzani et al., 2007; Volpato et al., 2007). In Europe, according to Vaz et al. (2007), this issue aroused the interest of several institutions. For example: The British Field Sports Society (BFSS) commissioned a review of the scientific literature regarding the welfare of fish (Pottinger, 1995). In 1995 the European Aquaculture Society started organizing debate on this topic at its conferences.

However, with respect to Brazil, the first law that addresses animal testing was passed in 1934 (Decree n. ${ }^{\circ}$ 24645 of July 10, 1934). This law established measures for the protection of animals and for the first time the State recognized the need to protect all animals in the country (Art. $\left.{ }^{\circ} 1\right)$. However, most of this article focu-ses on large animals (horses and cattle) (Vaz et al., 2007).

With respect specifically to fish, there are still no relevant regulations regarding welfare practices that take into account the welfare of fish. Probably because the debate on the welfare of farmed fish, only begins to be established and taking into account the few works dealing with the subject (Freitas \& Nishida, 1998; Volpato \& Barreto, 2001; Vaz et al., 2007; Viegas et al., 2012).

This study focuses on demonstrating what the members of a fishermen association (who grow tilapia and robalo peva) think about sentience and fish welfare at slaughter. This will help us determine if the topic is being considered during the commercial production of fish.

\section{Materials and Methods}

The study was undertaken in the traditional fishing community of Pedra D'Água $\left(18^{\circ} 43^{\prime} 05.86^{\prime \prime S}\right.$ and $39^{\circ} 48^{\prime} 50.38^{\prime \prime}$ ) in São Mateus, ES, Brazil. The community is involved in cage-cultivating fresh water estuarine fish, specifically tilapia (Oreochromis niloticus) and Robalo Peva (Centropomus parallelus). Study site selection was based on economic, social and technological need of the community, as well as partnership between the Centro Universitário Norte do Espírito 
Santo (CEUNES), the Federal University of Espírito Santo (UFES) and APESAM (Fishermen's Association of São Mateus), located in the community in question (Figure 1).

Based upon previous observation/knowledge of the local fish production process, interviews and literature search, we designed a questionnaire specifically designed with the tilapia culture in the area. There was monitoring of the performance and functionality of the activity (Freitas et al., 2009). Being that The Fishermen Association of São Mateus (APESAM - Associação dos Pescadores de São Mateus) consists of 22 members and has 164 cages for fish farming. This activity is an alternative income for fishermen, especially during the closed fishing periods.

Sampling was performed was non-probabilistic and by accessibility, using elements accessible for data collec tion, looking for reliable information that look in to account efficiency that represented the true characteristics of collected data (Gil, 2008).

The questionnaire was structured following an order of pre-established questions, whose order and wording remained constant for all persons interviewed. This questionnaire was individualized and possessing open and closed ended questions, the questions sought to identify the perception fish farmers had about slaughter methods, to identify shortcomings in the welfare of the fish and its influence on their commercial production.

This method proved to be the fastest and most efficient way of understanding the key aspects of the production chain, seeking clarifies what the fishermen knew and expected of the aquaculture activity. (Gil, 2008).

The interviews took place during a visit to the headquarters of APESAM on May 31, 2012. The data were

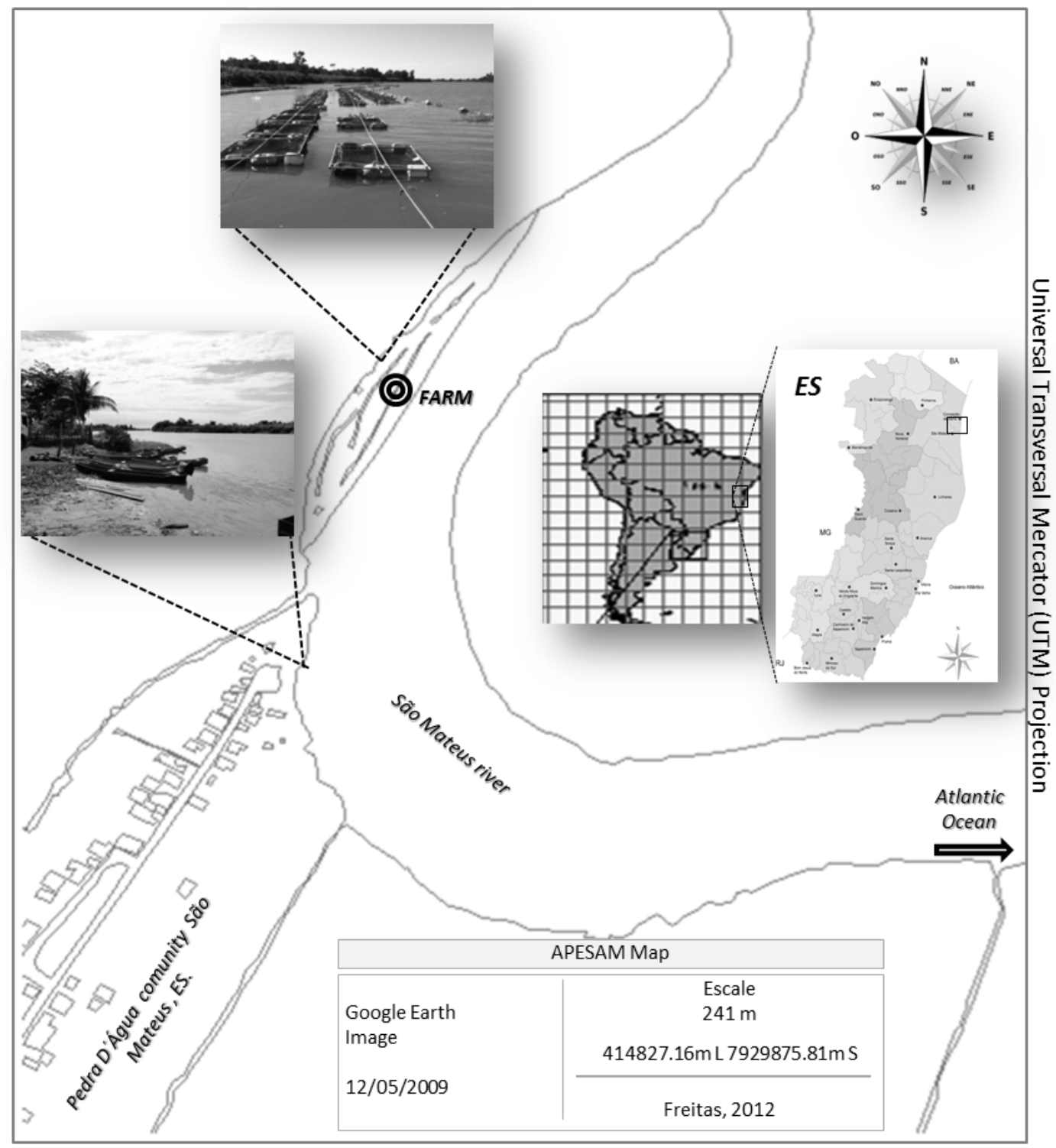

Figure 1 - Study area overview.

Figura 1 - Visão geral da área de estudo. 
gathered, between the months of May and July 2012, from nine individuals that were members of the association and that were available on site. Due to the pattern of responses compiled from the questionnaire, we determined the number of interview was satisfactory, on account of the patterns of responses obtained through interviews and there was no need to return on for additional interviews.

\section{Results and Discussion}

The present study suggests that, even without scientific proof of sentience in fish, fish farmers treat them humanely. This was substantiated through interviews, where according to the persons involved, the proper handling of fish resulted in higher weight, reduced contraction of diseases and reduced mortality. This appeared to be influenced by potential concerns over welfare (targeting the commercial side of the activity) and the fact that consumers did desire that the fish to be treated humanely (Figure 2).

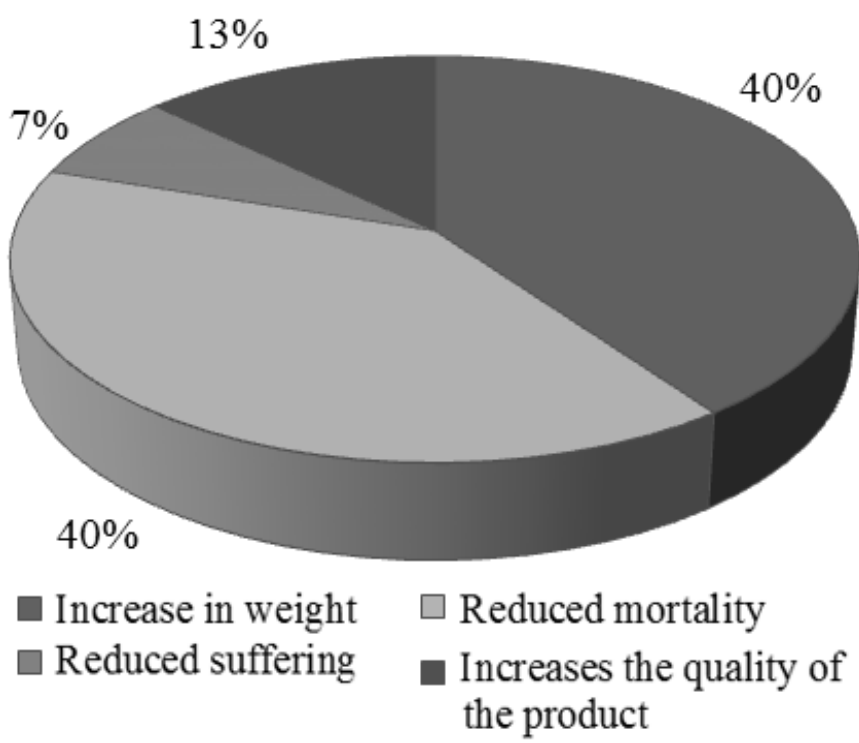

Figure 2 - Percentage of different reasons given by individuals tested of why the welfare of commercially produced fish is important.

Figura 2 - Percentual das diferentes razões apresentadas pelos indivíduos testados justificando a importância do bem-estar dos peixes na produção comercial.

As matter of fact, most scientists, philosophers and members of the public accept the idea that most animals are sentient (Turner, 2006). According to research conducted by Molento et al. (2001) and Bones et al. (2007), about $96 \%$ of people they tested believe that animals usually have "intelligence" and emotions, thought there was a lesser degree in recognition of sentience of fish than other animals.

Moreover, as society begins to recognize animal suffering as a relevant factor, an economic value is placed on animal welfare that becomes an integral part in the calculation of the economic value of animal products. There are studies that suggest that in societies that are more conscious of the importance of the welfare of commercially produced animals this can have significant cost-benefit ratios (Molento, 2005).

The expenditures associated with improving the quality of life of animals were a limiting factor for progress in the area, as the producers did not want to commit to higher expenses if the well-being was not a commodity. This situation has been changing animal welfare has become a growing concern in many countries (specially the most developed), with increasing societal demands for improvement in the quality of life. Thus animal welfare will be set up to as a non-tariff barrier of great importance (Molento, 2005; Gameiro, 2007).

In order to discuss welfare objectively, we need a better context, since the concept itself is interpreted in different ways (Dawkings, 1998), though most definitions fall into three categories, each addressing different aspects of significance. According to the Fisheries Society of The British Isles - FSBI (2002), the categories are based on feeling (what an animal feels being free from negative experiences while promoting positive experiences), role-based (centered on the animal's ability to adapt to the environment), and type (where the environment of each animal species is considered, and the captive environment should be a similar as possible to that found in the natural environment).

Regarding the category of feelings, only one person disagreed that fish could feel fear, but in general, the results suggest they were aware that fish have the ability to feel. In addition, the results suggest that the individuals interviewed try to prevent that the fish they handle meet predators, reducing the handling of fish and to avoid scaring the fish with sounds and disturbances in the water. Pedrazzani et al. (2007) reported that that under certain circumstances fish feel stressed, increasing the evidence that fish can sense and consciously respond to different stimuli (similarly to mammals) from the point of view of physiology and psychology.

Stress can be defined as a condition in which the dynamic equilibrium of the body (homeostasis) is threatened / disturbed by a stressor stimulus (Wendeelar Bonga, 1997). These factors can be of many types which can be divided into three main areas: the physical (such as shipping, handling or confinement), chemical (such as contaminants, low oxygen or low $\mathrm{pH}$ ), and those perceived from the environment by the animals (such as the presence of predators) (Barton, 1997).

The action of these factors may produce effects that threaten or disturb the body's balance, or cause a range of responses (such as remedial action and/or adaptive 
actions), enabling the animal to overcome the threat(s). Importantly, if the animal is subjected to intense and constant stress, the physiological response may lose its adaptive value and become dysfunctional, causing permanent damage to health and well-being (Carmichael, 1984).

In general, similar to occurrence in other vertebrates, we can name three levels of reaction/response to a stressor. The first would be an alarm reaction, which includes neuroendocrine changes resulting in the release of catecholamine and cortisol. The second attempt would be resistance and adaptation as a result of the levels of hormones released, altering movement of the rates of hormones, neurotransmitters conversion rates, the cardio respiratory rate and mobilization of energy reserves. The third stage is a state of exhaustion, including immune changes and those affecting in the rates of growth and reproduction, often leading to death (Galhardo \& Oliveira, 2006).

In addition, stress impairs growth due to effects on metabolism and endocrine changes that regulate growth. It is worth noting that the link between growth and fish metabolism is complex and less well understood that other mechanisms such as, for example - playback control (Silveira et al., 2009). In general, these adverse conditions could lead to a significant reduction in the productivity or development of the individual, which makes well-being of primary concern.

One way to address stress reduction was to maintain an environment similar to that found in nature. In this regard, members failed to show any relevant concern. According to them, it is difficult to adapt the culture environment (cages) to resemble the natural environment due to space constrains, as fish in the natural environment would have more "freedom". However, the maintenance of similarity between environments is not only limited to the issue of space.
In this regard, aquaculture activity is strictly dependent on the existing environment (and hence the ecosystem) in which it operates (Valenti, 2002). Water quality is an essential factor for the maintenance of an adequate environment, and according to Pedrazzani et al. (2007), environmental factors that are the focus of attention of research on stress in fish, both by industry and by research groups in welfare.

Another point addressed were the methods of slaughter, which is considered by Viegas et al. (2012) to be one of the greatest stress factors in fish production. All members interviewed reported that there were reprehensible ways to cull fish, citing as an example, "striking the head of the animal." The interviews listed five other methods that respondents scored them according to their opinions (just as cruel, cruel or too cruel). Figure 3 presents each method and their ratings.

In this regard, some authors claim (regarding warmblooded animals such as mammals and birds) that it is common to address welfare as a factor for both production and slaughter and as such, it has been established that unconsciousness/desensitization should be rapidly induced without neglecting the welfare and meat quality (Lambooij et al., 2002; Van De Vis et al., 2003; Terlouw et al., 2008; Andrade et al., 2009; Santana et al., 2009; Viegas et al., 2012).

According to Pedrazzani et al. (2007), the slaughtering techniques of fish have been carefully studied in order to look for improvements regarding safety procedures, quality control of the final product and minimizing the time required to kill the animal and to reduce emotions (such as fear and pain) during the process.

Traditionally, ease and reduced cost were the two main factors considered in the choice of slaughter methods for fish. But traditional methods, such as suffocation (in air or on ice), evisceration or heat shock are not considered humane, because they cause unnecessary suffering,

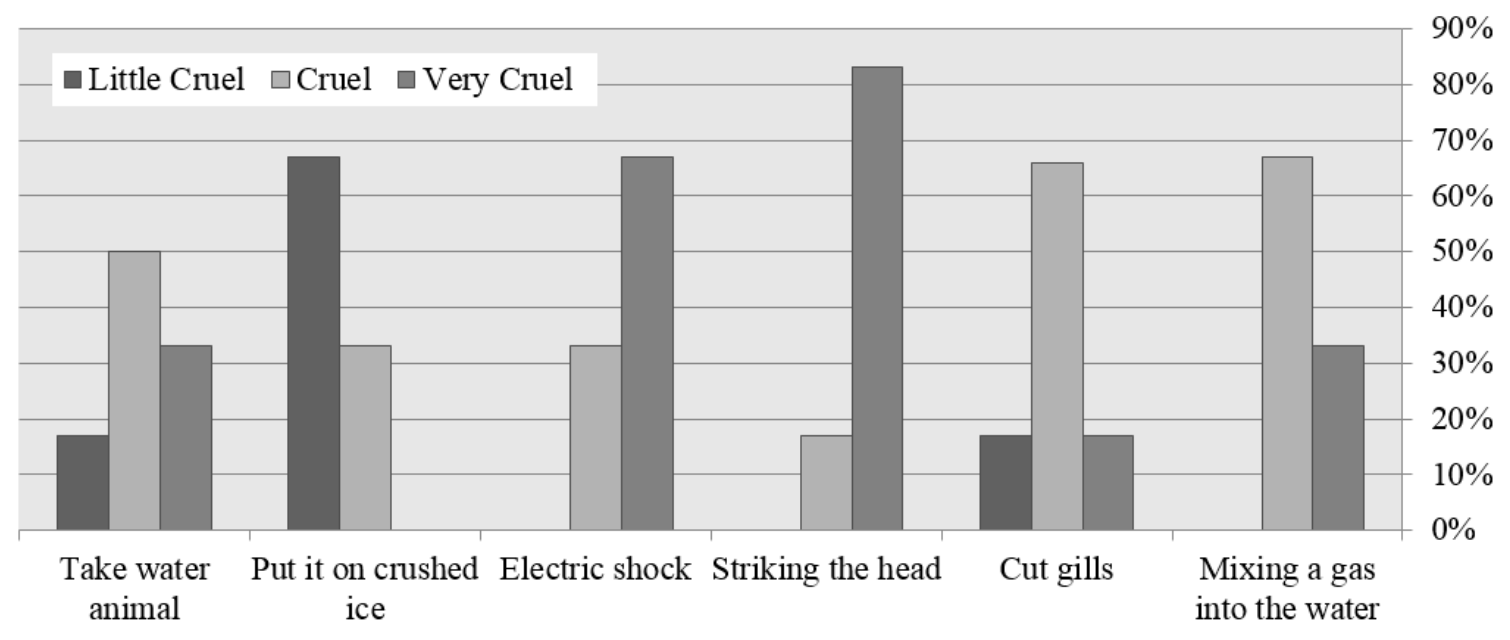

Figure 3 - Classification of methods of slaughter.

Figura 3 - Classificação dos métodos de abate. 
pain and stress, additionally diminish the quality of the product during storage (Viegas et al., 2012).

Furthermore, according Poli et al. (2005), the chemical reactions resulting from pain and stress at slaughter reduces the time to the onset of rigor-mortis in fish. Pain cause another set of reactions, which changes the $\mathrm{pH}$ of the flesh to nearly neutral, accelerating the action of the enzymes and promoting bacterial growth, resulting in a faster degradation of the fish. Studies by Roth et al. (2002) show the differences in the quality of postharvest fish using different methods of slaughter.

In general, we can conclude that the methods that cause the least amount of suffering and provide better meat quality are: stunning by electric shock, cranial percussion and anesthetic overdose. The killing of fish by suffocation in air or with ice, heat shock, narcotic gases or by salt bath caused too much stress and have significant effects on meat quality. Thus, it is not possible to recommend a single slaughter method to be used in several species of fish, making further research on the topic necessary (Viegas et al., 2012).

Another point of discuss was how to identify welfare shortcomings for fish. According to the members, a lack of well-being in cultivation was identified by excessive mortality, disease onset, atypical appearance, atypical behavior, and poor weight gain and color variation in the fish. According to Vaz et al. (2007), the bond between well-being and health is complex. If a fish showed signs of illness, this usually suggested that the cause might be associated with reduced state of well-being. However, this association may not be entirely true, as health-related welfare may be compromised for other factors.

The causes of fish diseases are complex and the risk increases when environmental conditions are poor (FSBI, 2002). However, it would incorrect to say that diseases are the result of poor growing conditions as even in a great environment for fish farming, fish contract diseases and eventually die.

Regarding the origin of topic, there was virtual unanimity in the interviews on three items: the market (distribution channel requiring), people (consumers are more concerned with the proper treatment of animals) and the University (science has shown that the welfare of animals is important).

As a scientific concern, the animal welfare owes its origin to public concerns about how animals are treated in captivity (Galhardo \& Oliveira, 2006). The dissemination of research confirming the sentience of animals makes the public more about the origin of their product. Therefore, the market must adapt to customer demands and sell fish that were grown under humane conditions. According Carneiro et al. (2007), the recognition of sentience in the fish population can be an advantage for the market, as products from farms employing humane conditions (that minimize suffering) may serve to establish a price differential when selling these products.

\section{Final Considerations}

Fish welfare is an area with where there is little literature available in Portuguese. Questions about suffering and pain are still controversial and no specific legislation exist governing methods of slaughter for fish. Ignorance on the physiological mechanisms in fish leads researchers to compare them with other species, especially mammals, which appears to be inappropriate. However, sentience (in and of itself) is suffering for us to worry about the welfare of some organism.

Furthermore, it is observe that the implementation of production systems that provide a high quality of life for animals resulted in significantly increased production costs, which served as a limiting factor for the development of welfare awareness. On the other hand, as the demand for products produced with concern for animal increases (because of information, awareness and public perception), wellness's may become a commodity.

The present study revealed that knowledge of the subject was not wide-spread enough to affect aquaculture, though as a matter of ethics or as an effort to improve productivity, farmers were concerned with well-being, which suggested that this could be the beginning of forward progress. On must remember that welfare was not necessarily associated with improvements in productivity, but for those involved in fish farming, it directly affected the mortality and fish weight, which in turn influenced productivity. Therefore, with respect to concerns about the welfare of fish, it would be essential to maintain a suitable is necessary for both a suitable environment for farming and an appropriate method of slaughter, resulting in lower stress levels which directly translate into better quality fish on the market.

\section{Acknowledgments}

This study was financed by Edital MCT/CNPq/CT-Agronegócio/MPA N $N^{\circ}$ 036/2009. Institution: Centro Universitário Vila Velha - UVV; FAPES processo \# 53235282/2011. Co-Institutions: UFES, CEUNES/UFES, INCAPER, IFES, UFSM. Rede Capixaba de Pesquisa com Robalo-Peva (Centropomus paralellus) RECAPER

\section{References}

Anonymous (2006) - Ethical justification for the use and treatment of fishes in research. Journal of Fish Biology 68(1):1-2. DOI: 10.1111/j.0022-1112.2006.01035.x

Barton, B.A. (1997) - Stress in finfish: Past, present and future - A historical perspective. In: G.K. Iwana, A.D. Pickering, J. Sumpter, C.B. Schreck, C.B. (eds.), Fish stresses and health in aquaculture, pp.1-33, Cambridge University Press, Cambridge, England, U.K. ISBN: 978-0521281706. Available on-line at http://books.google. com.br/books?isbn $=0521281709$ 
Benson, J.; Rollin, B.E. (2004) - The Well-Being of Farm Animals: Challenges and Solutions. 388 p., Blackwell Publishing, Ames, Iowa, IA, USA. ISBN: 978-0813804736.

Bones, V.C.; Nordi, W.M.; Marthos, S.M.; Molento, C.F.M. (2007) - Percepção e atitude da população em relação ao uso de animais para entretenimento em Curitiba, Paraná. Anais eletrônicos, Congresso Internacional de Conceitos em Bem-Estar Animal, Rio de Janeiro, RJ, Brazil. Available on-line at http://gege.agrarias.ufpr. br/Arquivos/Anais Con-ceitos de Bem Estar Animal.pdf

Branson, E. (2008) - Fish Welfare. 352p., Blackwell Publishing, Oxford, UK. ISBN: 978-1405146296. Available on-line at http://books.google.com.br/books?id=-NNIWxyXPIYC\&printsec=front cover\&hl=pt-BR $-\mathrm{v}=$ onepage\& $\mathrm{q} \& \mathrm{f}=$ false

Brown, C.; Braithwaite, V.A. (2005) - Effects of predation pressure on the cognitive ability of the poeciliid Brachiraphis episcope. Behavioral Ecology, 16(2):482-487. DOI: 10.1093/beheco/ari016

Carmichael, G.J. (1984) - Long distance truck transport of intensive lyre a red largemouth bass. Progressive Fish-culturist, 46(2):111115. DOI: 10.1577/1548-8640(1984)46<111:LDTTOI $>2.0 . C O ; 2$

Carneiro, P.C.F.; Molento, C.F.M.; Pedrazzani, A.S.; Castilho, M.F. (2007) - Bem-estar de peixes e a questão de senciência. Archives of Veterinary Science (ISSN: 1517-784X), 11(3):60-70, Universidade Federal do Paraná, Curitiba, PR, Brazil. Available on-line at http://ojs.c3sl.ufpr.br/ojs/index.php/veterinary/article/view /10929

Dawkins, M.S. (1998) - Evolution and animal welfare. The Quarterly Review of Biology (ISSN: 1539-7718), 73(3):305-328, University of Chicago Press, Chicago, IL, USA. Available on-line at http://www.jstor.org/stable/3036918

Dawkins, M.S. (2006) - Through animal eyes: what behaviour tell us. Applied Animal Behavior Science, 100(1-2):4-10. DOI: 10.1016/j.applanim.2006.04.010

Duncan, I.J.H. (2006) - The changing concept of animal sentience. Applied Animal Behavior Science, 100(1-2):11-19. DOI: 10.1016/j.applanim.2006.04.011.

Erickson, H.S. (2003) - Information Resources on Fish Welfare: 1970-2003. 436p., Dept. of Agriculture, National Agricultural Library, Animal Welfare Information Center. Beltsville, MD, USA. Available on-line at http://www.nal.usda.gov/awic/pubs/Fish welfare/fishwelfare.htm

Fraser, A.F.; Broom, D.M. (1996) - Farm Animal Behaviour and Welfare. 448p., Cab International, Wallingford, England, UK. ISBN: 978-0851991603.

Freitas, G.E.; Nishida, S.M. (1998) - Sneaking behaviour of the nile tilapia. Pirassununga, Boletim Técnico do CEPTA (ISSN: 01031112), 11(1):71-79, Centro de Pesquisa e Treinamento em Aquicultura - CEPTA, Pirassununga, SP, Brazil. Available on-line at http://www.icmbio.gov.br/cepta/images/stories/producao cientifica /sneaking_1998_01.pdf

Freitas, R.R.; Vinatea, L.; Netto, S. (2009) - Analysis of the marine shrimp culture production chain in Southern Brazil. Anais da Academia Brasileira de Ciências, 81(2):287-295. DOI: 10.1590/S0001-37652009000200015

FSBI (2002) - Fishwelfare (Briefing Paper 2). 25p., Granta Information Systems, Fisheries Society of the British Isles, Cambridge, England, UK. Available on-line at http://www.fsbi.org.uk/assets/briefwelfare-refs.pdf

Galhardo, L.; Oliveira, R. (2006) - Bem estar animal: um conceito legitimo para peixes? Revista de Etologia (ISSN 1517-2805), 8(1):51-61, Sociedade Brasileira de Etologia, São Paulo, SP, Brazil. Available on-line at http://pepsic.bvsalud.org/scielo.php?pid $=\mathrm{S} 1517-28052006000100006 \&$ script $=$ sci arttext

Gameiro, A. H. (2007) - Análise econômica e Bem-Estar animal em sistemas de produção alternativos: uma proposta metodológica. Anais eletrônicos, XLV Congresso da Sociedade Brasileira de Economia, Administração e Sociologia Rural, Londrina, PR,
Brazil. Available on-line at http://lae.fmvz.usp.br/pdf/2007 Gameiro sober.pdf.

Gil, A.C. (2008) - Métodos e Técnicas de Pesquisa Social. 220p., Atlas, São Paulo, SP, Brazil. ISBN 978-8522451425

Harrison, R. (1964) - Animal Machines: the new factory farming industry. 186p., Vincent Stuart LTD. London, England. ISBN: 978-0722400364.

Lambooij, E.; Van De Vis, J.W.; Kuhlmann, H.; Munkner, W.; Oehlenschlager, J.; Kloosterboer, R.J.; Pieterse, C. (2002) - A feasible method for humane slaughter of eel (Anguilla anguilla L.): electrical stunning in fresh water prior to gutting. Aquaculture Research, 33(9): 643-652. DOI: 10.1046/j.1365-2109.2002. 00677.x

Molento, C.F.M. (2005) - Bem-Estar e produção animal: aspetos econômicos - Revisão. Archives of Veterinary Science (ISSN: 1517-784X), 10(1):1-11, Universidade Federal do Paraná, Curitiba, PR, Brazil. Available on-line at http://ojs.c3sl.ufpr.br/ojs2/index.php/veterinary/article/viewArticle/4078

Molento, C.F.M.; Battisti, M.K.B.; Rego, M.I.C. (2001) - The attitude toward animals: people from the Northwestern Region of the State of Paraná, Southern Brazil. 75p., Anais, International Conference on Human-Animal interactions, Rio de Janeiro, RJ, Brazil.

Odling-Smee, L.; Braithwaite, V.A. (2003) - The role of learning in fish orientation. Fish and Fisheries, 4(3):235-246. DOI: 10.1046/j.1467-2979.2003.00127.x

Pedrazzani, A.S.; Molento, C.F.M.; Carneiro, P.C.F.; Fernandes-DeCastilho, M. (2007) - Senciência e bem-estar de peixes: uma visão de futuro do mercado consumidor. Panorama da Aqüicultura (ISSN: 1519-1141), 27(102):24-29, SRG Gráfica e Editora, Rio de Janeiro, RJ, Brazil. Available on-line at http://www.prp.ufla.br/site/wpcontent/uploads/2011/08/bem-estar-em-peixes.pdf

Poli, B.; Parisi, G.; Scappini, F.; Zampacavallo, G. (2005) - Fish welfare and quality as affected by pre-slaughter and slaughter management. Aquaculture International, 13(1-2):29-49. DOI: 10.1007/s10499-004-9035-1.

Pottinger, T.G. (1995) - Fish welfare literature review. 82p., Institute of Freshwater Ecology, Ambleside, Cumbria, UK. Available on-line at http://nora.nerc.ac.uk/7223/1/Fish_Welfare_Literature_Review _-_TG_Pottinger_-_1995.pdf

Rollin, B.E. (1995) - Farm Animal Welfare: School, Bioethics and Research Issues. 168p., Iowa State Press, Iowa, USA. ISBN: 9780813825632

Rose, J.D. (2002) - The neurobehavioral nature of fishes and the question of awareness and pain. Reviews Fish Science, 10(1):1-38. DOI: $10.1080 / 20026491051668$

Roth, B., Moeller, D., Veland, J.O., Imsland, A.; Slinde, E. (2002) The effect of stunning methods on rigor mortis and texture properties of Atlantic salmon (Salmo Salar). Journal of Food Science, 67(4):1462-1466. DOI: 10.1111/j.1365-2621.2002.tb10306.x

Sandoe, P.; Forkman, B.; Christiansen, S.B. (2004) - Scientific uncertainty - how should it be handled in relation to scientific advice regarding animal welfare issues? Animal Welfare (ISSN: 0962-7286), 13(Suppl.1):121-126, Universities Federation for Animal Welfare, Wheathampstead, Hertfordshire, England. Available on-line at http://www.ingentaconnect.com/content/ufaw/aw/2004/ 00000013/A00101s1/art00017

Santana, A.P.; Murata, L.S.; Macmanus, C.P.; Bernal, F.E.M. (2009) - Dosagem de cortisol sanguíneo em suínos submetidos ao manejo pré-abate e insensibilização elétrica. Archivos Zootecnia, 58(221):149-152. DOI: 10.4321/S0004-05922009000100021.

Silveira, U.S.; Logato, P.V.R.; Pontes, E.C. (2009) - Fatores estressantes em peixes. Revista Eletrônica Nutritime (ISSN 19839006), 6(4):1001-1017, Nutritime, Viçosa, MG, Brazil. Available on-line at http://nutritime.com.br/arquivos_internos/artigos/094V6N4P 1001_1017JUL2009_.pdf 
Sneddon, L.U. (2002) - Anatomical and electrophysiological analysis of the trigeminal nerve in a teleost fish, Oncorhynchus mykiss. Neuroscience Letters, 319(3):167-171. DOI: 10.1016/ S0304-3940(01)02584-8

Sneddon, L.U. (2003a) - Trigeminal somatosensory innervation of the head of a teleost fish with particular reference to nociception. Brain Research, 972(1-2):44-52. DOI: 10.1016/S0006-8993(03) 02483-1.

Sneddon, L.U. (2003b) - The evidence for pain in fish: the use of morphine as an analgesic. Applied Animal Behavior Science, 83(2):153-162. DOI: 10.1016/S0168-1591(03)00113-8.

Sneddon, L.U.; Braithwaite, V.A.; Gentle, M.J. (2003) - Novel object test: Examining nociception and fear in the rainbow trout. Journal of Pain, 4(8):431-440. DOI: 10.1067/S1526-5900(03) 00717-X

Terlouw, E.M.C.; Arnould, C.; Auperin, B.; Berri, C.; Bihan-Duval, E.L.; Deiss, V.; Lefevre, F.; Lensink, B.J.; Mounier, L. (2008) Pre-slaughter conditions, animal stress and welfare: current status and possible future research. Animal, 2(10):1501-1517. DOI: 10.1017/S1751731108002723.

Turner, J. (2006) - Stop, look and listen: recognizing the sentience of farm animals. 48p., Compassion in World Farming Trust, Petersfield, Hampshire, UK. ISBN 190-0156393. Available on-line at http://www.fao.org/fileadmin/user_upload/animalwelfare/stop_ look_listen_2006.pdf

Vaarst, V.; Roderick, S.; Lund, V.; Lockeretz, W.; (2004) - Animal Health and Welfare in Organic Agriculture. 448 p., Cab International, Cambridge, England. ISBN: 085199668X. Available online at http://books.google.com.br/books? id=eKUldHkCTAsC\&printsec= frontcover\&hl=pt-BR- $\mathrm{v}=$ onepage $\& \mathrm{q} \& \mathrm{f}=$ false

Valenti, W.C. (2002) - Aquicultura sustentável. p.111-118., Anais eletrônicos, $12^{\circ}$ Congresso de Zootecnia, Associação Portuguesa dos Engenheiros Zootécnicos, Vila Real, Portugal. Available on-line at http://www.caunesp.unesp.br/publicacoes/artigos/valenti/CPIL VALENTI_Aquicultura sustentavel.pdf
Van de Vis, H.; Kestin, S.; Robb, D.; Oehlenschlager, J.; Lambooij, B.; Munkner, W.; Kuhlmann, H.; Kloosterboer, K.; Tejada, M.; Huidobro, A.; Ottera, H.; Roth, B.; Sorensen, N.K.; Akse, L.; Byrne, H.; Nesvadba, P. (2003) - Is humane slaughter of fish possible for industry?. Aquaculture Research, 34(3):211-220. DOI: 10.1046/j.1365-2109.2003.00804.x.

Vaz, B.S.; Lopes, P.R.S.; Enke, D.B.S.; Pouey, J.L.F.O. (2007) Aspectos sobre bem-estar em peixes cultivados. Revista Brasileira de Agrociência (ISSN: 0104-8996), 13(4):419-422, Universidade Federal de Pelotas, Pelotas, RS, Brazil. Available on-line at http://www.ufpel.edu.br/faem/agrociencia/v13n4/artigo01.pdf

Viegas, E.M.M.; Pimenta, F.A.; Previero, T.C.; Gonçalves, L.U.; Durães, J.P.; Ribeiro, M.A.R.; Oliveira Filho, P.R.C. (2012) Métodos de abate e qualidade da carne de peixe. Archivos Zootecnia (ISSN: 1885-4494), 61(1):41-50, Universidad de Córdoba, Córdoba, Spain. Available on-line at http://www.uco.es/organiza/ servicios/publica/az/php/img/web/10_11_37_1915REVISIONMetodos Viegas.pdf

Volpato, G.L. (2007) - Considerações metodológicas sobre os testes de preferência na avaliação do bem-estar em peixes. Revista Brasileira de Zootecnia, 36(suppl.):53-61. DOI: 10.1590/S151635982007001000006.

Volpato, G.L.; Barreto, R.E. (2001) - Environmental blue light prevents stress in the fish Nile tilapia. Brazilian Jornal of Medical and Biological Research (ISSN: 1414-431X), 34(8):1041-1045, Faculdade de Medicina de Ribeirão Preto/USP, Ribeirão Preto, SP, Brazil. Available on-line at http://www.scielo.br/pdf/bjmbr/v34n8 /4190.pdf

Volpato, G.L.; Freitas, E.G.; Castilho, M.F. (2007) - Insight into the concept of fish welfare. Diseases of Aquatic Organisms, 75(2): 165-171. DOI: 10.3354/dao075165.

Wendeelar Bonga, S.E. (1997) - The stress response in fish. Physiol Review (ISSN: 1522-1210), 77(3): 591-625, American Physiological Society, Rockville, MD, USA. Available on-line at http://physrev.physiology.org/content/77/3/591.long 